\title{
Progress in Tree Fruit Improvement Through Molecular Genetics
}

\author{
Ralph Scorza \\ U.S. Department of Agriculture-Agricultural Research Service, Appalachian Fruit Research Station, 45 Wiltshire \\ Road, Kearneysville, WV 25443
}

The new biotechnologies being developed and used for the genetic improvement of plant species have the potential to revolutionize tree fruit breeding. Development of new tree fruit cultivars has been plagued by generation cycles of 3-20 years, high levels of heterozygosity, severe inbreeding depression, complex intraspecific incompatibility relationships, and nucellar embryony. The production of many major fruit crops, including apple (Malus $\times$ domestica Borkh.), citrus, and pear (Pyrus communis L.), is based on a rather limited number of cultivars, and in many cases these cultivars were selected many years ago as chance seedlings. Because of the long-term nature of tree fruit breeding, the vast majority of tree fruit breeding programs are publicly funded and the funds available for these programs continues to decline. The application of new technologies that will speed the pace of tree improvement is critically needed if tree fruit breeding is to remain a viable endeavor.

Notwithstanding the current debate concerning the acceptance of transgenic food crops (de Kathen, 1998; Hoban, 1997; Hoban and Katic, 1998; Mann, 1999), the technology for development and release of new transgenic cultivars and the acreage covered by them continue to increase. Genetic mapping continues to progress at an ever increasing pace, providing breeders with the tools to make rapid progress in crop improvement, and "functional genomics" promises to provide insights into genetic regulation of plant function and the means for isolating genes that can be manipulated in transgenic plants. In a limited way, these advances in plant improvement have begun to be used for tree fruits, but, for the most part, work in these crops lags far behind that in many of the herbaceous species. Of the 5894 field releases of transgenic plants in the United States from 1987 to Apr. 2000 , only 33 have been temperate tree fruit species (www.aphis.usda.gov/bbep/bb; www.aphis.usda.gov/biotech). Tree fruit biotechnology has been the topic of several reviews (Oliveira et al., 1996; Schuerman and Dandekar, 1993; Scorza, 1991; Singh and Sansavini, 1998; Srinivasan and Scorza, 1999; Sung and An, 1997). The following discussion of tree fruit biotechnology outlines some of the research in progress. It is not meant to be exhaustive, but rather to provide an overall view of work in this area, citing relevant examples from a few of the leading programs.

\section{TRANSGENICS}

The difficulty in regeneration of many tree fruit species and/or cultivars is one of the most serious hindrances to the application of gene transfer technologies to these crops. In those species that can be reliably transformed, a careful reading of the literature generally reveals that few genotypes of a particular species are being transformed, and, in some cases, these genotypes are not commercially important cultivars. In some species, transformation has been obtained only from seedling material (da Câmara Machado and da Câmara Machado, 1995; Mante et al., 1991; Smigocki and Hammerschlag, 1991). The time between initiating a transformation experiment and the evaluation of phenotype is generally much longer for tree fruits than for herbaceous crops (Sherman and Lyrene, 1983). In the case of fruit-specific traits, evaluation typically takes place years after the initial transformation. The space requirements for evaluation of trees

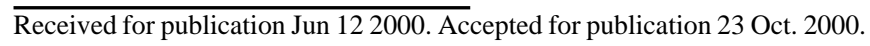
The cost of publishing this paper was defrayed in part by the payment of page charges. Under postal regulations, this paper must be hereby marked advertisement solely to indicate this fact.

E-mail address: rscorza@asrr.arsusda.gov can be significant, and, coupled with the need for multiple-year evaluation in different growing areas, make evaluation of transgenic tree fruits expensive and time-consuming. The requirements for evaluating the performance of new transgenic cultivars of tree fruits are the same as those required for conventional cultivar development; thus, the incorporation of molecular genetics within existing breeding programs is perhaps the most efficient approach to the development of improved transgenic tree fruit cultivars.

Difficulties notwithstanding, there are several inherent advantages in the use of gene transfer for tree fruit improvement. Once a useful transformant is isolated, assuming stability of transgene expression (and this assumption has yet to be adequately tested for tree fruits), vegetative propagation - the normal route of multiplying tree fruitsprovides for virtually unlimited production of the desired transgenic line. Fixation through the sexual cycle is not required. The dominance of a few major cultivars in many tree fruit crops such as pear, apple, sour cherry (Prunus cerasus L.), and citrus maximizes the impact that an improved transgenic cultivar can have. For example, over $90 \%$ of U.S. pear production can be accounted for by three cultivars, 'Bartlett', 'Beurre Bosc', and 'Anjou'. An improvement in any of these three, particularly 'Bartlett', which accounts for $\approx 50 \%$ of the North American crop (O'Rourke, 1999), can have a significant impact on production. Currently, almost all of the sour cherry production in the United States is based on 'Montmorency'. Over 50\% of the world and U.S. apple crop is based on 'Red Delicious', 'Golden Delicious', 'Granny Smith', 'Gala', and 'Fuji' (O'Rourke, 1998). While this heavy reliance on a few major cultivars is not favorable in terms of genetic vulnerability, it is, in fact, the current situation, although breeding programs are releasing new cultivars that will broaden the genetic base. The current major cultivars, though, can potentially be improved in fruit quality and made less vulnerable to insects and diseases through transformation.

Most work in transformation of perennial tree fruits is concentrated in apple, citrus, pear and Prunus. Research focuses on disease and insect resistance, manipulation of fruit ripening/softening, and alteration of tree architecture.

\section{Apple}

Transgenic apples ('Royal Gala', 'Galaxy') expressing the lytic peptide attacin $E$ have been produced, and tests indicate that some transformants are more resistant to fireblight [caused by Erwinia amylovora [(Burr.) Winslow et al.] (Ko et al., 2000). A research group at Cornell Univ. is pursuing resistance to scab [caused by Venturia inaequalis (Cooke) G. Wint.] and apple insect pests using chitinase genes from various sources. Delayed fruit softening is being pursued through expression of sense and antisense 1-aminocyclopropane 1carboxylic acid (ACC)-synthase and polygalacturonase genes. Evaluation of fire blight resistance, delayed fruit softening, and scab resistance are in the field-test stage (Bolar et al., 2000).

Work at the Univ. of California at U.C. Davis by Dandekar and coworkers on apple improvement is at the field test stage and focuses on improving fruit shelf life through the manipulation of ethylene biosynthesis. Transgenic apple trees that incorporate sense or antisense cDNA encoding ACC-synthase and ACC-oxidase from apple are under field-test (Dandekar, pers. comm.). Resistance to codling moth [Cydia pomonella (L.)], using a chemically synthesized version of the cryIAc gene from Bacillus thuringiensis (Bt) with improved codon usage pattern, has been successfully field tested (Dandekar, pers. comm.), and is currently being commercialized by Dry Creek Labora- 
tories, Modesto, Calif. Sorbitol is the major product of photosynthesis in apple and many other members of the Rosaceae, and its role in carbon metabolism is being evaluated by studying transgenic apple trees expressing sense/antisense cDNA that encodes sorbitol-6-phosphate dehydrogenase, the enzyme that catalyzes the key step in sorbitol biosynthesis. Trees with alterations in sorbitol metabolism are currently being field tested (Dandekar, pers. comm.) to evaluate the role of sorbitol in growth, photosynthetic efficiency, and productivity of trees and quality and yield of fruit.

Research on the regulation of apple and pear ripening through down regulation of ethylene biosynthesis is being undertaken by researchers at Agritope, Inc., Beaverton, Ore., where the $s a m-k$ gene encoding S-adenosylmethionine hydrolase (SAMase) has been engineered into 'Gale Gala' apple and 'Bartlett' pear (Bommineni et al., 2000). Transgenic plants are under field evaluation. The effects of this gene on ripening have not yet been evaluated.

The growth of apple trees has been altered by the expression of the rolA gene isolated from Agrobacterium rhizogenes. M.26 apple rootstocks transformed with $\mathrm{rolA}$ had reduced internode length, reduced leaf area, and lower dry weights than did controls (Holefors et al., 1998). Grafting 'Gravenstein' onto transgenic M.26 stocks expressing rolA reduced stem and internode length of the scion, but the transformed rootstocks did not influence relative growth rate, leaf area ratio, specific leaf area, or dry matter allocation of the scion (Zhu and Welander, 1999).

\section{Pear}

As with apple, resistance to fire blight is a major goal of pear improvement through transformation. Transgenic pears expressing the attacin $E$ lytic peptide gene have been produced (Reynoird et al., 1999). Eleven transgenic 'Passe Crassane' clones were obtained, with eight showing a high level of transcription. In comparison with the nontransformed control, necrosis was significantly reduced in six clones, but symptoms were still about six times as severe as those shown by the highly resistant cultivar Old Home. Researchers at USDA-ARS, Kearneysville, W.Va., are currently testing transgenic 'Bartlett' pear plants expressing lytic peptide genes for resistance to fire blight (Bell et al., pers. comm.).

There is also a critical need for smaller pear trees for high-density production systems. Transgenic dwarf pears have been produced through the introduction of the rolC gene from Agrobacterium rhizogenes (Bell et al., 1999). Greenhouse tests of three transgenic clones showed significant reductions in height, number of nodes, internode length, and leaf area in comparison with nontransformed 'Beurre Bosc' controls. These trees are currently under field evaluation as scions and rootstocks, and additional transgenic trees are being produced using rolC and other genes that cause dwarfing in other species.

\section{Citrus}

The development of highly efficient citrus transformation systems has led the way to the testing of many genes in this economically important genus (Cervera et al., 1998; Luth and Moore, 1999; Moore et al., 1992; Peña et al., 1995). Traits under study for improvement include resistance to citrus tristeza virus (CTV) using CTV-derived genes (Dominguez et al., 1999), PR protein genes for resistance to Phytophthora, Arabidopsis floral genes, such as Leafy $(L F Y)$ and Apetala $1(A P 1)$, to shorten the juvenile period, genes derived from citrus to control tree growth, and yeast-derived genes for salt tolerance (Cervera et al., 2000). Many of these transgenic trees are currently under greenhouse test at Instituto Valenciano de Investigaciones Agrarias, Valencia.

\section{Prunus}

Although Prunus species account for $\$ 1.5$ billion in revenue in the United States alone, transformation is far from routine for most species. Almond [Prunus dulcis (Mill.) D.A. Webb], apricot (P. armeniaca L.), cherry, peach, and plum ( $P$. domestica $\mathrm{L}$.) have been transformed, but most published papers have been single reports involving only the introduction of marker genes (da Camara Machado et al., 1995; da Câmara Machado and da Câmara Machado, 1995; Mante et al., 1991; Miguel and Oliveira, 1999; Negri et al., 1998; Smigocki and Hammerschlag, 1991). Transformation from mature somatic tissues (i.e., cultivars) is even more rare (da Camara Machado et al., 1995; Miguel and Oliveira, 1999; Negri et al., 1998). The improvement goals for Prunus sp. are similar to those for other tree fruit species and include disease and insect resistance, delayed softening, and manipulation of tree architecture. Transgenic peach seedlings expressing the tms328::Tn5-cytokinin gene from A. tumefaciens were reduced in height and/or branched more than did controls (Hammerschlag and Smigocki, 1998). Transgenic cherry plants expressing the phytochrome A (Phy A) gene, which alters growth habit, are currently under test (Negri et al., 1998). Transformation of seedderived explants of European plum with the plum pox virus (PPV) coat protein gene has produced trees highly resistant to this virus in both greenhouse and field tests (Ravelonandro et al., 1997; Scorza et al., 1994). Hybrids produced from transgenic, resistant parents carrying the PPV-CP insert were also PPV-resistant (Scorza et al., 1998). Seedderived apricot has also been transformed with the PPV coat protein gene (da Câmara Machado and da Câmara Machado, 1995).

Manipulation of fruit ripening/softening is being pursued at USDA/ ARS Kearneysville by transformation of $P$. domestica with antisense ACC-oxidase. Transgenic trees are under field test (Callahan, pers. comm.). Application of this technology to peach is being pursued.

\section{MARKER-ASSISTED SELECTION}

Molecular markers have the potential for speeding the breeding process and reducing costs. The prospect of selecting promising seedlings at an early stage of growth in the greenhouse by using a saturated map to tag quantitative traits, as well as those controlled by single genes, and planting only these promising genotypes in the field, is an attractive prospect. Also the possibility of using molecular markers as tools for map-based cloning of genes presents new exciting possibilities for tree fruit breeders.

Linkage maps in apple, peach, peach $\mathrm{x}$ almond hybrids, sour cherry, and sweet cherry (Prunus avium L.) have been published (Abbott et al., 1998; Chaparro et al., 1994; Conner et al., 1997; Davis and Yu, 1997; Dirlewanger and Bodo, 1994; Foolad et al., 1995; Hemmat et al., 1994; Joobeur et al., 1998; Maliepaard et al., 1998; Rajapakse et al., 1995; Sosinski et al., 1998; Stockinger et al., 1996; Viruel et al., 1995; Wang et al., 1998).

In peach, the eight linkage groups have been identified and RFLP probes have been shared among Prunus mapping groups so that homologous linkage groups can be identified. Apple maps of 1120 and $984 \mathrm{cM}$ have been developed representing the 17 linkage groups (Hemmat et al., 1994; Maliepaard et al., 1998).

The European community has published a general Prunus linkage map based on an interspecific cross between peach and almond (Joobeur et al., 1998). This map contains 213 mapped genomic and cDNA probes from a number of different Prunus species. No linkage maps are available for pear or plum.

In almond, eight linkage groups covering $394 \mathrm{cM}$ with an average of $4.2 \mathrm{cM}$ between markers were identified (Viruel et al., 1995). The sour cherry map consists of 18 linkage groups covering $508 \mathrm{cM}$ (Wang et al., 1998). In sweet cherry the map consists of 10 linkage groups covering $503 \mathrm{cM}$.

Economically important genes have been tagged in peach and apple. In peach, three markers were found to be closely linked $(1.3 \mathrm{cM})$ to Freestone $(\mathrm{F})$, the locus controlling the stone/flesh adherence trait (Sosinski et al., 1998). Amplified fragment length polymorphism (AFLP) markers have been identified in peach that are $3.4 \mathrm{cM}$ and 6.0 cM away from the two genes for nematode resistance $(M i$ and $M i j)(\mathrm{Lu}$ et al., 1998, 1999), and $1 \mathrm{cM}$ away from the "Evergreen" locus (Wang et al., 2000b). In apple, markers flanking the $V f$ gene for scab resistance have been identified (Patocchi et al., 1999), as well as a simple sequence repeat (SSR) for the columnar $(\mathrm{Co})$ growth habit (Hemmat et al., 1997).

Within apple, peach, and cherry, quantitative trait loci (QTLs) have 
been identified, primarily for fruit quality (diameter, weight, juice $\mathrm{pH}$, sugars, soluble solids, phenolics), growth habit (bloom time, juvenility, branching habit), and pest resistance (Abbott et al., 1998; Conner et al., 1998; Dirlewanger et al., 1996,1998; Sosinski et al., 1998; Wang et al., 2000a). However, fine mapping of these QTLs is hampered by the difficulty of generating and maintaining the requisite large population sizes.

Peach and almond are genetically very similar and fully interfertile (Kester and Asay, 1975), and these species have been used for comparative mapping studies. Because of the limited amount of polymorphism in intraspecific crosses, two of the earliest linkage maps published in Prunus were constructed from peach $\mathrm{x}$ almond crosses (Foolad et al., 1995; Viruel et al., 1995). The locus order and the $\mathrm{cM}$ distances in the interspecific peach $\mathrm{x}$ almond map were not substantially different from those in the almond map (Viruel et al., 1995). The only other published comparative mapping effort within the Rosaceae is the comparison of the sour cherry map with the peach/ almond map (Wang et al., 1998).

\section{CONCLUSIONS}

Rapid progress in the practical application of transformation for the genetic improvement of tree fruits will depend on the development of reliable, efficient, genotype-independent transformation systems. Meristem transformation using biolistics (Sautter et al., 1995) or a combination of biolistics and Agrobacterium (Zimmerman and Scorza, 1996), appear to be promising approaches, but will require a considerable investment of effort. As with transformation of any species, the development of useful transgenic tree fruits will require the use of carefully chosen promoters that provide expression at the required time and in the required tissue. Gene discovery will be important. Presently, the availability of potentially useful genes, especially from fruit species, is quite limited.

As with transformation research, the most efficient use of genomics research will occur when these technologies are integrated into active breeding programs. In the case of marker development, the markers are only as accurate as the field evaluation of the traits marked. The production, maintenance, and evaluation of useful mapping populations are critical to map development. Field work must be completely integrated into mapping studies and funded accordingly. Without field programs, the benefits of the new transformation and genomics technologies will not be available to the industry and consumers.

\section{Literature Cited}

Abbott, A.G., S. Rajapakse, B. Sosinski, Z.X. Lu, K. Sossey-Alaoui, M. Gannavarapu, R. Scorza, G. Reighard, R.E. Ballard, A. Callahan, and W.V. Baird. 1998. Construction of saturated linkage maps of peach crosses segregating for characters controlling fruit quality, tree architecture and pest resistance. Acta Hort. 465:141-50.

Bell, R.L., R. Scorza, C. Srinivasan, and K. Webb. 1999. Transformation of 'Beurre Bosc' pear with the rolC gene. J. Amer. Soc. Hort. Sci. 124:570574.

Bolar, J.P., J.L. Norelli, K.-W. Wong, C.K. Hayes, G.E. Harman, and H.S. Aldwinckle. 2000. Expression of endochitinase from Trichoderma harzianum in transgenic apple increases resistance to apple scab and reduces vigor. Phytopathology 90:72-77.

Bommineni, V.R., H. Mathews, S.K. Clendennen, W. Wagoner, V. Dewey, J. Kellogg, S. Peters, W. Matsumura, M. Pieper, M. Kramer, and D.R. Wagner. 2000. Genetic engineering of fruits and vegetables with the ethylene control gene encoding S-adenosylmethionine hydrolase (SAMase), p. 206-214. In: A.D. Arencibia (ed.). Plant genetic engineering: Towards the third millennium. Elsevier Science B.V.

Cervera, M., J. Juárez, A. Navarro, J.A. Pina, N. Duran-Vila, L. Navarro, and L. Peña. 1998. Genetic transformation and regeneration of mature tissues of woody fruit plants bypassing the juvenile stage. Transgenic Res. 7:5159.

Chaparro, J.X., D.J. Werner, D. O’Malley, and R.R. Sederoff. 1994. Targeted mapping and linkage analysis of morphological, isoenzyme, and RAPD markers in peach. Theor. Appl. Genet. 87:805-815.

Conner, P.J., S.K. Brown, and N.F. Weeden. 1997. Randomly amplified polymorphic DNA-based genetic linkage maps of three apple cultivars. J. Amer Soc. Hort. Sci. 122:350-359.
Conner, P.J., S.K Brown, and N.F. Weeden. 1998. Molecular-marker analysis of quantitative traits from growth and development in juvenile apple trees. Theor. Appl. Genet. 96:1027-1035.

da Câmara Machado, A. and M.L. da Câmara Machado. 1995. Genetic transformation in Prunus armeniaca L. (apricot), p. 240-254. In: Y.P.S. Bajaj (ed.). Biotechnology in agriculture and forestry, vol. 34. Plant protoplasts and genetic engineering VI. Springer-Verlag, Berlin.

da Câmara Machado, A., M. Puschmann, H. Pühringer, R. Kremen, H. Katinger, and M.L. da Câmara Machado. 1995. Somatic embryogenesis of Prunus subhirtella autumno rosa and regeneration of transgenic plants after Agrobacterium-mediated transformation. Plant Cell Rpt. 14:335340.

de Kathen, A. 1998. The debate on risks from plant biotechnology: The end of reductionism? Plant Tissue Cult. Biotech. 4:136-147.

Dirlewanger, E. and C. Bodo. 1994. Molecular genetic mapping of peach. Euphytica 77:101-103.

Dirlewanger, E., A. Moing, V. Pronier, L. Svanella, A. Guye, R. Monet, and C. Rothan. 1998. Detection of QTLs controlling peach fruit acidity and sweetness. Acta Hort. 465:89-98.

Dirlewanger, E., T. Pascal, C. Zuger, and J. Kervella. 1996. Analysis of molecular markers associated with powdery mildew resistance genes in peach [Prunus persica (L.) Batsch] x Prunus davidiana hybrids. Theor. Appl. Genet. 93:909-919.

Domínguez, A., J. Guerri, M. Cambra, L. Navarro, P. Moreno, and L. Peña. 1999. Efficient production of transgenic citrus plants expressing the coat protein gene of citrus tristeza virus. Plant Cell Rpt. 18:

Foolad, M.R., S. Arulsekar, V. Becerra, and F.A. Bliss. 1995. A genetic linkage map of Prunus based on an interspecific cross between peach and almond. Theor. Appl. Genet. 91:262-269.

Hammerschlag, F.A. and A.C. Smigocki. 1998. Growth and in vitro propagation of peach plants transformed with the shooty mutant strain of Agrobacterium tumefaciens. HortScience 33:897-899.

Hemmat, M., N.F. Weeden, P.J. Conner, and S.K. Brown. 1997. A DNA marker for columnar growth habit in apple contains a simple sequence repeat. J. Amer. Soc. Hort. Sci. 122:347-349.

Hemmat, M., N.F. Weeden, A.G. Manganaris, and D.M. Lawson. 1994. Molecular-marker linkage map for apple. J. Hered. 85:4-11.

Hoban, T.J. 1997. Consumer acceptance of biotechnology: An international perspective. Nature Biotech. 15:232-234.

Hoban, T.J. and L.D. Kaatic. 1998. American consumer views on biotechnology. Cereal Foods World 43:20-22.

Holefors, A., Z.T. Xue, and M. Welander. 1998. Transformation of the apple rootstock M26 with the rolA gene and its influence on growth. Plant Sci. 136:69-78.

Joobeur, T., M.A. Viruel, M.C. de Vicente, B. Jauregui, J. Ballester, M.T. Dettori, I. Verde, M.J. Truco, R. Messeguer, I. Batlle, R. Quarta, E. Dirlwanger, and P. Arus. 1998. Construction of a saturated linkage map for Prunus using an almond $x$ peach $\mathrm{F}_{2}$ progeny. Theor. Appl. Genet. 97:10341041

Kester, D.E. and R.N. Asay. 1975. Almond, p. 387-419. In: J. Janick and M. Moore (eds.). Adv. in fruit breeding, Purdue Univ. Press, W. Lafayette, Ind.

Ko, K.S., J.L. Norelli, J.P. Reynoird, E. Boresjza-Wysocka, S.K. Brown, and H.S. Aldwinkle. 2000. Effect of untranslated leader sequence of AMV RNA 4 and signal peptide of pathogenesis-related protein $1 \mathrm{~b}$ on attacin gene expression, and resistance to fire blight in transgenic apple. Biotech Lett. 22:373-381.

Lu, X-Z., S. Sosinski, G. Reighard, W.V. Baird, and A.G. Abbott. 1998. Construction of a genetic linkage map and identification of AFLP markers for resistance to root-knot nematodes in peach rootstocks. Genome 41:199207.

Lu, Z-X., K. Sossey-Alaoui, G.L. Reighard, W.V. Baird, and A.G. Abbott. 1999. Development and characterization of a codominant marker linked to root-knot nematode resistance and its application to peach rootstock breeding. Theor. Appl. Genet. 99:115-122.

Luth, D. and G. Moore. 1999. Transgenic grapefruit plants obtained by Agrobacterium tumefaciens-mediated transformation. Plant, Cell, Tissue, Organ Cult. 57:219-222.

Maliepaard, C., F.H. Alston, G. van Arkel, L.M. Brown, E. Chevreau, F. Dunemann, K.M. Evans, S. Gardiner, P. Guilford, and A.W. van Huesden. 1998. Aligning male and female linkage maps of apple (Malus pumila Mill.) using multi-allelic markers. Theor. Appl. Genet. 97:60-73.

Mann, C.C. 1999. Biotech goes wild. Tech. Rev. July/Aug., p. 37-43.

Mante, S., P.H. Morgens, R. Scorza, J.M. Cordts, and A.M. Callahan. 1991. Agrobacterium-mediated transformation of plum (Prunus domestica L.) hypocotyl slices and regeneration of transgenic plants. Bio/Technology 9:853-857.

Miguel, C.M. and M.M. Oliveira. 1999. Transgenic almond (Prunus dulcis Mill.) plants obtained by Agrobacterium-mediated transformation of leaf explants. Plant Cell Rpt. 18:387-393. 
Moore, G.A., C.C. Jacono, J.L. Neidigh, S.D. Lawrence, and K. Cline. 1992 Agrobacterium-mediated transformation of Citrus stem segments and regeneration of transgenic plants. Plant Cell Rpt. 11:238-242.

Negri, P., E. Magnanini, L. Cantoni, G. Berardi, and S. Sansavini. 1998. Piante arboree transgeniche: Prime esperienze sul transferimento di geni per il controllo dell'habitus vegetativo. Rivista di Frutticoltura 5:91-97.

Oliveira, M.M., C.M. Miguel, and M.H. Raquel. 1996. Transformation studies in woody fruit species. Plant Tissue Cult. Biotech. 2:76-91.

O'Rourke, D. 1999. World pear review, 1999 ed. Belrose, Pullman, Wash.

O’Rourke, D. 1998. World apple report, 1998 ed. Belrose, Pullman, Wash.

Patocchi, A., B.A. Vinatzer, L. Gianfranceschi, S. Tartarini, S. Sansavini, and C. Gesler. 1999. Construction of a $500 \mathrm{~kb}$ BAC contig in apple spanning the genomic region containing the Vf scab resistance gene, p. 105. In: Proc. Plant and Animal Genome VII, San Diego, Calif.

Peña, L., M. Cervera, J. Juárez, C. Ortega, J.A. Pina, N. Durán-Vila, and L. Navarro. 1995. High efficiency Agrobacterium-mediated transformation and regeneration of citrus. Plant Sci. 104:183-191.

Rajapakse, S., L.E. Belthoff, G. He, A.E. Estager, R. Scorza, I. Verde, R.E Ballard, W.V. Baird, A. Callahan, R. Monet, and A.G. Abbott. 1995 Genetic linkage mapping in peach using morphological, RFLP and RAPD markers. Theor. Appl. Genet. 90:503-510.

Ravelonandro, M., R. Scorza, J.C. Bachelier, G. Labonne, L. Levy, V. Damsteegt, A.M. Callahan, and J. Dunez. 1997. Resistance of transgenic Prunus domestica to plum pox virus infection. Plant Dis. 81:1231-1235.

Reynoird, J.P., F. Mourgues, J. Norelli, H.S. Aldwinkle, M.N. Brisset, and E Chevreau. 1999. First evidence for improved resistance to fire blight in transgenic pear expressing the attacin E gene from Hyalophora cecropia. Plant Sci. 149:23-31.

Sautter, C., N. Leduc, R. Bilang, V.A. Iglesias, A. Gisel, X. Wen, and I. Potrykus. 1995. Shoot apical meristems as a target for gene transfer by microballistics. Euphytica 85:45-51.

Schuerman, P.L. and A. Dandekar. 1993. Transformation of temperate woody crops: Progress and potentials. Scientia Hort. 55:101-124.

Scorza, R. 1991. Gene transfer for the genetic improvement of perennial fruit and nut crops. HortScience 26:1033-1035.

Scorza, R., A.M. Callahan, L. Levy, V. Damsteegt, and M. Ravelonandro. 1998. Transferring potyvirus coat protein genes through hybridization of transgenic plants to produce plum pox virus resistant plums (Prunus domestica L.). Acta Hort. 472:421-427.

Scorza, R., M. Ravelonandro, A.M. Callahan, J.M. Cordts, M. Fuchs, J. Dunez, and D. Gonsalves. 1994. Transgenic plums (Prunus domestica L.) express the plum pox virus coat protein gene. Plant Cell Rpt. 14:18-22.

Sherman, W.B. and P.M. Lyrene. 1983. Handling seedling populations, p. 6673. In: J.N. Moore and J. Janick (eds.). Methods in fruit breeding. Purdue Univ. Press, West Lafayette, Ind.

Singh, Z., and S. Sansavini. 1998. Genetic transformation and fruit crop improvement. Plant Breeding Rev. 16:87-134.

Smigocki, A.C. and F.A. Hammerschlag. 1991. Regeneration of plants from peach embryo cells infected with a shooty mutant strain of Agrobacterium. J. Amer. Soc. Hort. Sci. 116:1092-1097.

Sosinski, B., Z.X. Lu, A. Tabb, K. Sossey-Alaoui, S. Rajapakse, K. Glassmoyer, R. Scorza, G. Reighard, R.E. Ballard, W.V. Baird, and A.G. Abbott. 1998. Use of AFLP and RFLP markers to create a combined linkage map in peach [Prunus persica (L.) Batsch] for use in marker assisted selection. Acta Hort. 465:61-68.

Srinivasan, C. and R. Scorza. 1999. Transformation of somatic embryos of fruit trees and grape vine, p. 313-330. In: S.M. Jain, P.K. Gupta, and R.J. Newton (eds.). Somatic embryogenesis in woody plants vol. 5. Kluwer Academic, U.K.

Stockinger, E.J., C.A. Mulinix, C.M. Long, T.S. Brettin, and A.F. Iezzoni. 1996. A linkage map of sweet cherry based on RAPD analysis of a microspore-derived callus culture population. J. Hered. 87:214-218.

Sung, S.K. and G. An. 1997. Trends of genetic study of forest tree and development of useful traits for apple biotechnology. J. Plant Biol. 40:164 169

Viruel, M.A., R. Messeguer, M.C.d. Vicente, J. Garcia-Mas, P. Puidomènech, F. Vargas, and P. Arús. 1995. A linkage map with RFLP and isozyme markers for almond. Theor. Appl. Genet. 91:964-971

Wang, D., R. Karle, T.S. Brettin, and A.F. Iezzoni. 1998. Genetic linkage map in sour cherry using RFLP markers. Theor. Appl. Genet. 97:1217-1224.

Wang, D., R. Karle, and A.F. Iezzoni. 2000a. QTL analysis of flower and fruit traits in sour cherry. Theor. Appl. Genet. 100:535-544.

Wang, Y., G.L. Reighard, R. Scorza, and A. Abbott. 2000b. Identification of molecular markers linked to the Evergreen gene in peach [Prunus persica (L.) Batsch], p. 332. In: Plant and Animal Genome VIII Conf., San Diego, Calif.

Zhu, L.H. and M. Welander. 1999. Growth characteristics of apple cultivar Gravenstein plants grafted onto the transformed rootstock M26 with rolA and rolB genes under non-limiting nutrient conditions. Plant Sci. 147:7580 .

Zimmerman, T.W. and R. Scorza. 1996. Genetic transformation through the use of hyperhydric tobacco meristems. Mol. Breeding 2:73-80. 